\title{
Correspondence
}

\section{Smiles at the Unobtrusive}

SIR, - A second round of supercilious comment on my quantitative estimates of scientific manpower (Nature, April 4, 1970, p. 10) leaves me wondering about the status of my unknown assailant. It rominds me of the regrets expressed long ago in these columns that perhaps the editor of Nature was being confused with its author. At all events I protest the imperious editorial attitude and remind you that the protecting shelter of anonymity carries an implied responsibility in speaking for the British scientific community. One would have no objection to a signed statement by a mere person who might find that my (or any other) social science investiga.tion of scientists was distasteful or even loathsome. Indeed, the resistance of scientists to such intrusive examinations of themselves is well known, and though it is not pleasant, it has been a most illuminating and revealing topic of serious discussion and analysis by sociologists of science. With an unsigned editorial it is different. It surely ill behoves scientists in Britain to countenance an official attitude of this sort towards serious social science investigations into such things as the geographic distribution of scientific manpower, and any regularities and laws there might be connecting such parameters with other demographic variables. Such investigations have long exercised my respected colleagues in several countries and are hallowed by Unesco and OECD. British science policy is neither so competent and well managed nor so replete with reliable statistics that the establishment can afford just to smile at things which may be learned from these unobtrusive indicators of the deployment of our resources.

I ignored the first round of editorial humour (Nature, 217, 793; 1968), supposing that its purpose was merely to amuse the readers or to draw me into a personal controversy in which opinions of scientists about science might be entertaining. My attitude towards my work is, however, not much different from that of a physicist or a chemist towards theirs. I do not publish with the principal objective of debate for an amusable public, but in the hope of adding something to knowledge before the audience of pecrs. If Nature contains on its editorial staff or among contributors those who are seriously eritical and competent in the matters of estimates of scientific manpower and literature, let them speak and be very welcome indeed. The concept of a "publishing scientist" is open to a great deal of uncertainty but it gives a consistent body of reasonable laws and hopefully a rather useful analysis of a difficult problem that I would be happy to see discussed. If not, $I$ think that the editor of Nature would be well advised to check the boisterousness of that part of himsolf that would poke fun at the antics of social scientists. The tradition of William Petty to actuarial arithmotic is not to be mocked by those who are that contemptuous of their colleagues as to think it stupid to count anything so individual and so beyond the reach of science as a human being or a "publishing scientist".

\section{Yours faithfully,}

Derek J. de Solla Price

Department of History of Science

and Medicine,

Box 2036, Yale Station,

Now Haven, Conn. 06520.

\section{Mediocrity of Ks}

Str,-N. W. Pirie (Nature, May 23, 1970) is wrong in supposing that the learned societies discriminate against alphabetical tail-enders. An inspection of the London Telephone Directory-whose subscribers we presume to be an alphabetical cross-section of London's populationhas a mid-point approximately at "Kingsley" (towards the end of the $\mathrm{Ks}$ ). This is presumably because of the infrequency of names beginning with $\mathrm{Q}, \mathrm{U}, \mathrm{V}, \mathrm{X}, \mathrm{Y}$ and $\mathrm{Z}$.

The mid-points of the lists of members of the learned societies mentioned by Pirie therefore occur where they would be expected to (allowing for some statistical variations expected in small samples) were there no alphabetical discrimination.

$$
\text { Yours faithfully, }
$$

\section{R. Brows}

R. WEST

National Institute for Medical Research, Mill Hill,

London NW7.

\section{Divisions among Kings}

Sir,-Mr Pirie (Nature, May 23, 1970) suggests that there is a forward shift in the alphabet in name lists of persons recruited on the basis of apparent merit. This suggestion was based on a comparison of the list of members of the Royal Society and the National Academy of Sciences (mid-point in the $\mathrm{Ks}$ ) with the membership lists of the Biochernical and Nutrition Societies (mid-point in the Ls). It is true that one would not expect to find selection in the latter case, and this prompted me to look in other, pre. sumably unbiased, lists that happened to be handy, with the following results: Institute of Physics and Physical Society 1966 membership list, mid-point KING; Institute of Metals 1964/65 list, KHAN; resident members of the University of Oxford 1968/69, men KING, women KENT; the Oxford Area telephone directory 1969 (which includes businesses and institutions), KINGFEAST. The name KING is again found by opening in the middle the 3360 page Who's Who 1958.

The 1969 list of fellows of the Royal Society, excluding royalty and foreign members, shows that the mid-point is at KENT, so there is, after all, surely nothing to suggest that there has been any alphabetical bias in the selection of the fellowship. What is peculiar is the apparent back. ward shift into the Ls of the membership of the Biochemi. cal and Nutrition Societies as reported by Mr Pirie.

Yours faithfully,

\section{G. L'E. TuRNER}

46 Hamilton Road, Oxford.

\section{Dr Bruce and Astrophysics}

SIR,---In two reports published by the Electrical Research Association in 1955 and 1958 (refs. 1 and 2) Dr C. E. R. Bruce showed that the electrification of dust in cosmic atmospheres, and the breakdown of the resulting electric fields in electrical discharges, would account for the data of astrophysies in general and the radiation from and 
characteristics of radio galaxies in particular. It is noteworthy that the association of the surprisingly intenso radiation from quasars with dust was confirmed soon after their discovery ${ }^{3}$, thus confirming Dr Bruce's prediction made eight ycars earlier. This and the theory's many other successes, many of them also demonstrably predictions, are outlined in another recent ERA Report ${ }^{4}$, so that it is rather surprising that in their recent noto Okuda and Wickramasinghe ${ }^{5}$, while confirming Dr Bruce's suggestion as to the importance of dust in the universe, profess ignorance as to the nature of the energy source associated with it.

The novelty of many of these theoretical predictions makes their subsequent confirmation by observations all the more cogent. For example, when the highest solar temperature then discussed was only around a million degrees, Dr Bruce deduced that the temperature in solar flare discharges must reach hundreds of inillions of degrees. The existence of these tempcratures was confirmed by the discovery of X-rays from solar flares the following year. Dr Bruce's electrical discharge theory of solar flares would appcar to have been confirmed beyond a doubt by A. B. Severny's? discovery, probably one of the most important astronomical obsorvations ever made, that the transverso magnetic fields surrounding two solar flares in 1966 aro such as would be caused by electric currents in the flares.

$$
\text { Yours faithfully, }
$$

\section{B. C. Lindeley}

Electrical Rescarch Association,

Clevo Road,

Leatherhead, Surrey.

'Bruce, C. E. R., ERA Report Ref. Z/T101 (Phil. Mag., 46, 1123; 1955).

'Bruce, C. E. R., ERA Report, Ref. Z/T117 (1958).

${ }^{3}$ Burbidge, E. M., and Burbidge, G. R., in Quasi Stellar Sources and Gravitational Collapse (edit.by Robinson, I., Schild, A., and Shucking, E. L., 300 and 306 (Chicago Univ. Press, 1965).

${ }^{4}$ Bruce, C. E. R., ERA Report 5275 (1968).

${ }_{5}^{5}$ (okuda, H., and Wickramasinghe, N. C., Nature. 226, 134 (1970).

${ }^{6}$ Bruce, C. E. R., Nature, 184, 2004 (1959).

Bruce, C. E. R., Nature, 187, 865 (1960).

8 Severny, A. B. (personal communication).

\section{Announcements}

\section{University News}

Dr Robert B. Leighton has been appointed chairman of the Division of Physics, Mathematics and Astronomy, California Institute of Technology, in succession to Dr Carl D. Anderson.

Professor W. J. H. Butterfield has been appointed vice-chancellor of the University of Nottingham, in succession to Professor F. S. Dainton.

Dr M. A. Stephens, Mecill University, has been appointed to the new chair of mathematical statistics, Dr R. A. Lawrie has becn promoted to the new ehair of food science and Dr P. S. Pell has been promoted to the sccond chair of civil engineering, all in the University of Nottingham.

Dr Eric M. Wilson has been appointed to a personal chair in hydraulic engineering in the Department of Civil Engineering, University of Salford.

\section{Appointments}

Sir Ashley Miles has joined the board of trustces of the Beit Memorial Fellowships for Medical Research, in succession to Sir Alan N. Drury.

The Salk Institute has appointed Dr Frederick de Hoffmann to the new post of chancellor. Dr de Hoffmann was the founder 15 ycars ago of the research laboratory known as General Atomics, since absorbed by the Gulf Corporation and now known as Gulf General Atomic.

The British Nutrition Foundation has announced the ereation of two new offices, to replace that of directorgeneral, held by Dr Alastair Frazer until his death last June. Professor F. G. Young, University of Cambridge, has been appointed president of the Foundation (a parttime position), and Miss Dorothy Hollingsworth, who is at present head of the Food Science Advice Branch of the Ministry of Agriculture, Fisheries and Food, will become full-time director of the Foundation in August.

\section{Miscellaneous}

The Duke of Northumberland has been elected a Fellow of the Royal Socicty, under that statute which provides for the election of porsons who either have rendered conspicuous service to the cause of science or are such that their election would be of signal benefit to the Society.

Awards from the Ethel Behrens Fund are available to Fellows of the Chemical Society who are studying for their first degree at a British university or technical college, to assist with maintenance and travelling expenses incurred in attending the annual meeting of the Society. This meeting will bo held in Brighton from March 31 to April 3, 1971. Further information can be obtained from the Scientific Affairs Officer of the Society, Burlington House, London WIV OBN.

Twenty grants from the Chemical Society's Research Fund, each of $£ 50$, will be awarded to Follows of the Society for the year 1971. Applications will be considered on a merit basis, but preferenee will bo given to those working in less well endowed establishments. Further details can be obtained from the Administrative Officer, The Chemical Society, Burlington House, London W1V OBN.

Erratum. The contents entry for the article by N. R. Blacklow and A. Z. Kapikian "Serological Studies with EB Virus in Infectious Lymphocytosis" (Nature, 226, 647; 1970) should have been Infectious lymphocytosis, not Infectious mononucleosis. In the article itself, five lines from the end, read "these children" not "three children".

\section{International Meetings}

June 29-July 3, The Harnessing of Science and its Application to Assist in Day to Day Management, London (Derek Osborne, Operational Research Society Ltd, 64 Cannon Stroct, London EC4).

July 1, 8, 15, 22, 29, August 5, 12, 19, 24, 26, Will Rogers' Teaching and Training Institute Summer Seminars, Saranac Lake, NY (Montague Memorial Library, Will Pogers Hospital, Saranac Lake, NY, USA).

July 15-17, Testing Fibrous Composites for Mechanical Properties, Teddington (Dr S. L. S. Thomas, National Physical Laboratory, Teddington, Middlesex). 